Article

\title{
Synthesis of 9-Hydroxystearic Acid Derivatives and Their Antiproliferative Activity on HT 29 Cancer Cells
}

\author{
Natalia Calonghi ${ }^{1, *}$, Carla Boga ${ }^{2, *(\mathbb{D})}$, Dario Telese ${ }^{2}$, Silvia Bordoni ${ }^{2}$, Giorgio Sartor ${ }^{1}(\mathbb{D}$, \\ Chiara Torsello ${ }^{1}$ and Gabriele Micheletti ${ }^{2}$ (I) \\ 1 Department of Pharmacy and Biotechnology, University of Bologna, 40127 Bologna, Italy; \\ giorgio.sartor@unibo.it (G.S.); chiara.torsello@virgilio.it (C.T.) \\ 2 Department of Industrial Chemistry 'Toso Montanari', Alma Mater Studiorum Università di Bologna Viale \\ Del Risorgimento 4, 402136 Bologna, Italy; dario.telese2@unibo.it (D.T.); silvia.bordoni@unibo.it (S.B.); \\ gabriele.micheletti3@unibo.it (G.M.) \\ * Correspondence: natalia.calonghi@unibo.it (N.C.); carla.boga@unibo.it (C.B.); Tel.: +39-051-2091231 (N.C.); \\ $+39-051-2093616$ (C.B.)
}

Academic Editor: Luigi A. Agrofoglio

check for updates

Received: 27 September 2019; Accepted: 12 October 2019; Published: 15 October 2019

\begin{abstract}
Hydroxystearic acid (9-HSA) is an endogenous cellular lipid that possesses antiproliferative and selective effects against cancer cells. A series of derivatives were synthesized in order to investigate the effect of the substituent in position 9 and on the methyl ester functionality on the biological activity. The two separate enantiomers of methyl 9-hydroxystearate and of methyl 9-aminostearate showed antiproliferative activity against the HT29 cell line. This indicates the importance of position 9 groups being able to make hydrogen bonding with the molecular target. Further, this effect must be preserved when the carboxy group of 9-HSA is esterified. The biological tests showed that the amines, contrarily to methyl esters, resulted in cytotoxicity. A deep investigation on the effect of methyl (R)-9-hydroxystearate on HT29 cells showed an antiproliferative effect acting through the CDKN1A and MYCBP gene expression.
\end{abstract}

Keywords: 9-hydroxystearic acid; methyl 9-hydroxystearate; methyl 9-aminostearate; cancer

\section{Introduction}

9-Hydroxystearic acid (9-HSA, Figure 1) is an endogenous cellular lipid that possesses a natural negative regulatory activity of tumor cell proliferation. [1-3] Its content has been found greatly diminished in cancer cells with respect to the corresponding normal line [1] and its exogenous administration to adenocarcinoma (HT29), [4] osteosarcoma (U2OS, [5] or SaOS [6]) cancer cell lines results in a significant inhibition of the proliferation rate, as well as a significant increase of p53-independent p21 expression. [4] The expression of the cell cycle kinase inhibitor CDKN1A (P21) is induced in neoplastic cells by inhibitors of histone deacetylase 1 (HDAC1). Actually, the authors found that 9-HSA acts as a competitive inhibitor of the HDAC1 (histone deacetylase 1) isoform $[7,8]$. The studies of molecular docking [7] showed an interaction between the 9-HSA carboxy group and the zinc ion in the active site of HDAC1, by a mechanism similar to that already known for HDAC inhibitors such as valproate, butyrate, trichostatin A (TSA), and suberoylanilidehydroxamic acid (SAHA, Vorinostat) [9]. The molecular docking also predicted a more favorable binding energy for the HDAC1-(R)-9-HSA complex, with respect to the complex formed with the opposite enantiomer $(S)-9-H S A$. Enantiopure ( $R$ )-9-HSA is more easily accessible within the natural chiral pool since its precursor, (S)-dimorphecholic acid, is one of the main components of seeds of the genus Dimorphotheca plants [10]. Thus, both the (R)-9-HSA and its enantiomer were synthesized, and the docking prediction experimentally confirmed [11]. Based on the above, the importance of both the carboxy- and the hydroxyl- group in inducing the antiproliferative activity of 9-HSA is apparent. 
<smiles>CN[C@@H](O)C(=O)O</smiles>

(R)-9-HSA<smiles>CC[C@H](O)CC(=O)O</smiles>

(S)-9-HSA

Figure 1. The two enantiomeric forms of 9-hydroxystearic acid, an HDAC inhibitor.

Hence, this study made some modifications on these key positions to better enlighten the role played by these functionalities and to design, if possible, some structure-activity relationships. Herein, the results obtained are reported.

\section{Results and Discussion}

\subsection{Synthesis of 9-HSA Derivatives}

The 9-HSA derivatives synthesized and investigated are in Figure 2.<smiles>CC[C@H](O)CC(=O)OC</smiles>

(R)-1<smiles>CC[C@H](O)C(=O)OC</smiles>

$(S)-1$<smiles>CCC(C)OS(=O)(=O)c1ccc(C)cc1</smiles>

$(R)-2$<smiles>COC(=O)C(C)OC</smiles>

3<smiles>CC[C@@H](N)NC(=O)OC</smiles>

$(S)-4$<smiles>CC[C@H](N)CC(=O)OC</smiles>

(R)-5<smiles>COC(=O)C[C@H](C)N</smiles>

$(S)-5$

Figure 2. 9-HSA derivatives synthesized and biologically tested.

Compounds ( $R$ )-2 and 3 bear an ester and an ether group bound to the C-9, respectively, and this difference might give information on the free hydroxyl functionality about the biological action. Further, this study planned to prepare the relative amine (S)-5 isosteric structure, to gain information on the biological behavior of the methyl 9-hydroxystearate and methyl 9-aminostearate. This study decided to test also the biological activity of the azide (S)-4 species, as precursor of the mentioned amine species.

All compounds shown in Figure 2 were obtained starting from methyl (9R)-9-hydroxystearate [(R)-1], which in turn was obtained from Dimorphotheca sinuata seeds, which is oil, as well as the seeds of other plants of the genus Dimorphotheca. These contain high amounts of $(9 S, 10 E, 12 E)$ 9-hydroxyoctadeca-10,12-dienoic acid [(S)-dimorphecholic acid] [11], a precursor of $(\boldsymbol{R})$-1 and of (R)-9-HSA. The natural availability of (S)-dimorphecholic acid is a green and efficient way to obtain 9-HSA derivatives with the C-9 chiral carbon atom in enantiopure form, permitting all the difficulties exhibited by alternative synthetic methods [12] to be overcome. Scheme 1 shows the synthetic strategy adopted to prepare compounds (R)-1, (R)-2, 3, (S)-4 and (S)-5. 
<smiles>[R]C(=O)OCC(COC([R])=O)OC([R])=O</smiles>

Dimorphotheca sinuata seed oil (schematic representation) $\mathrm{CH}_{3} \mathrm{ONa} / \mathrm{CH}_{3} \mathrm{OH}$
$0^{\circ} \mathrm{C}, 2 \mathrm{~h}$ $0^{\circ} \mathrm{C}, 2 \mathrm{~h}$
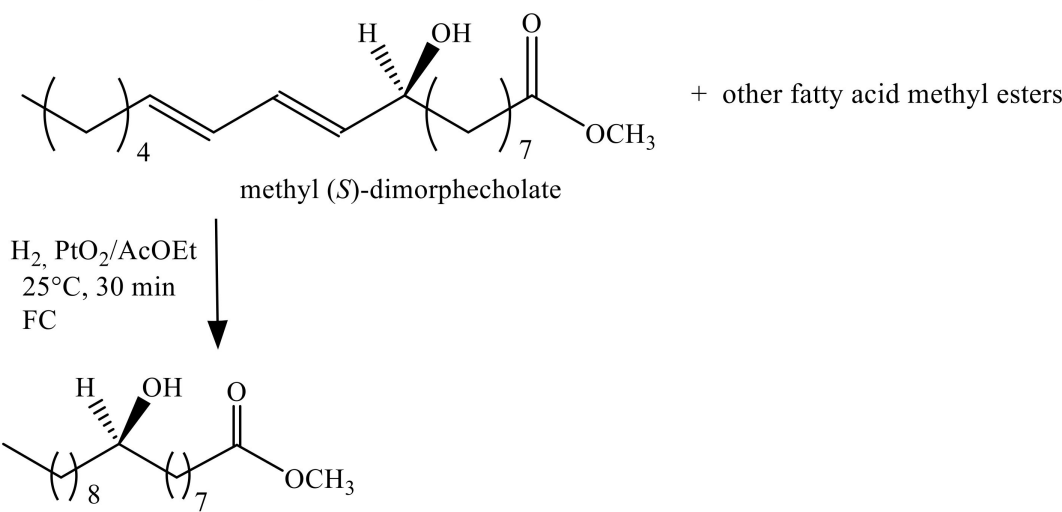

(R)-1

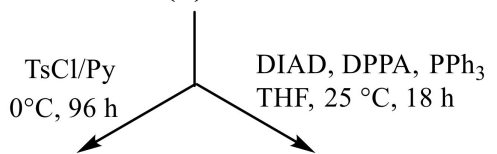<smiles>CCC(C)OS(=O)(=O)c1ccccc1</smiles>

$(R)-2$

$\mathrm{CH}_{3} \mathrm{OH}$

reflux, $8 \mathrm{~h}$<smiles>COC(=O)CC(C)C</smiles>

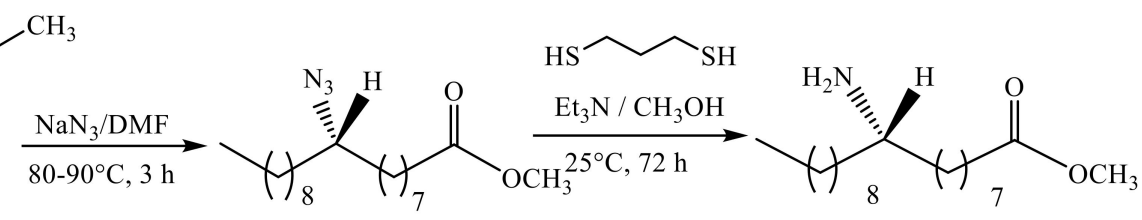

$(S)-4$

Scheme 1. Synthetic routes to 9-HSA derivatives.

The procedure appears to be the first reaction of transmethylation of the triglycerides, obtained from the extraction of the seeds and subsequent hydrogenation over the Adam's catalyst. After purification of the crude product by silica gel chromatography, the (9R)-methyl-9-hydroxystearate [(R)-1] was isolated and its optical purity was ascertained by ${ }^{1} \mathrm{H}$ NMR upon derivatization with $(R)$-O-acetylmandelic acid [10].

Compound $(\boldsymbol{R}) \mathbf{- 1}$ was then transformed by treatment with tosyl chloride into $(\boldsymbol{R})-\mathbf{2}$. The reaction of $(R)-2$ with refluxing methanol produced the methyl ether 3 . For the latter, the absolute configuration of the C-9 chiral center is not defined due to the possibility of occurrence, together with an inversion of the configuration, and also of a $S_{N} 1$ mechanism producing racemization. The addition to (R)-2 of sodium azide in $N, N$-dimethylformamide (DMF) at $80-90{ }^{\circ} \mathrm{C}$ produced the azide $(S)-4$. However, 
due to difficulties of the work-up and purification steps, an alternative method was adopted by reacting (R)-2 with diphenylphosphoryl azide (DPPA) under Mitsunobu conditions yielding (S)-4 in satisfactory yield $(77 \%)$.

The last step was devoted to the reduction of the azide. The adoption of Bayley's method (1,3-propandithiol and $\mathrm{Et}_{3} \mathrm{~N}$ ) [13] suffered a particularly hard work-up: After the separation of the amine from by-products through immobilization on the Dowex resin and subsequent release with triethylamine, a further treatment by liquid-liquid extraction was required and the desired amine was recovered in $13 \%$ yield. This encouraged the study to try the alternative synthetic route shown in Scheme 2 that gave, after purification, the amine $(S)-5$ in $36 \%$ overall yield from $(R)-1$.

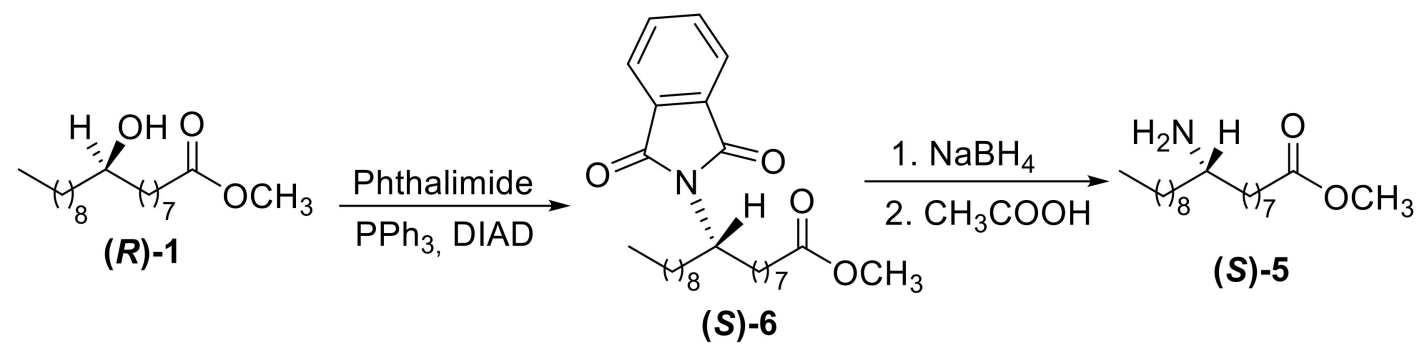

Scheme 2. Synthetic pathway to obtain aminoderivative (S)-5 from (R)-1.

The enantiopurity of the new amine (S)- 5 was ascertained by reacting it with the acyl chloride of the (S)-O-acetylmandelic acid (7) (Scheme 3 ) and by calculating, from the ${ }^{1} \mathrm{H}-\mathrm{NMR}$ spectrum of the crude, the ratio between the two diastereomeric amides $(S, S)-8$ and $(R, S)-8$. The signals were falling at 3.669 and $3.665 \mathrm{ppm}$, belonging to the $(S, S)$ and $(R, S)$ diastereomer, respectively, from which a 9/1 $d r$ was calculated, which was an indication of an almost complete inversion of the configuration during synthesis (see Figures S1-S17). This was confirmed by adding a little amount of the $(R, S)-8$ diastereomer (obtained as described below) to the above mixture: A sensitive increase of the area of the peak at 3.665 ppm was observed.

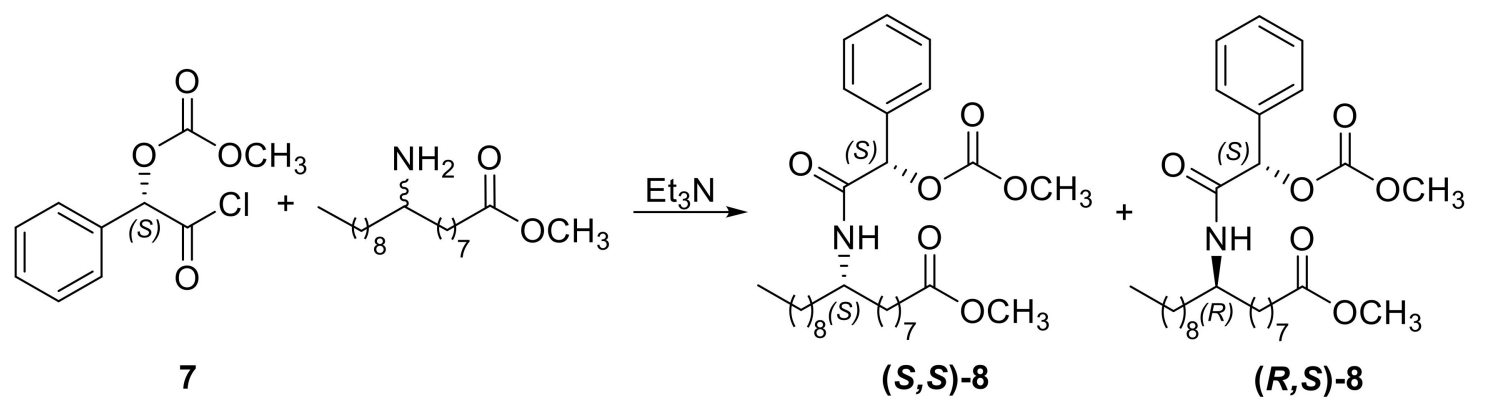

Scheme 3. Derivatization of the amine 5 with (S)-2-chloro-2-oxo-1-phenylethyl methyl carbonate (7) to determine the $(S, S)-8 /(R, S)-8$ diastereomeric ratio.

As reported in Scheme 1, several steps of the synthetic pathway imply the inversion of configuration on C-9 producing the compounds 4 and $\mathbf{5}$ with the $(S)$ configuration. Since the two enantiomers showed distinct antiproliferative activity by the preliminary tests in the case of 9-HSA, this study planned to prepare the opposite enantiomers of those compounds that, in preliminary tests, were biologically active. Thus, (S)-1 and (R)-5 were prepared in order to compare the biological activity of the two enantiomers (Figure 2), and to evaluate the trend in biological activity ascribed to both the isosters with same configuration.

The procedure utilized is shown in Scheme 4: (S)-1 was obtained by the inversion of the chiral center of $(\boldsymbol{R})-\mathbf{1}$ through the Mitsunobu reaction followed by the treatment of the intermediate $\mathbf{9}$ with methanolic $\mathrm{KOH}$ and esterification with $\mathrm{BF}_{3} / \mathrm{CH}_{3} \mathrm{OH}$. Then, $(\boldsymbol{R})-\mathbf{5}$ was obtained from (S)-1 by the same procedure depicted in Scheme 2 to obtain the opposite enantiomer. 


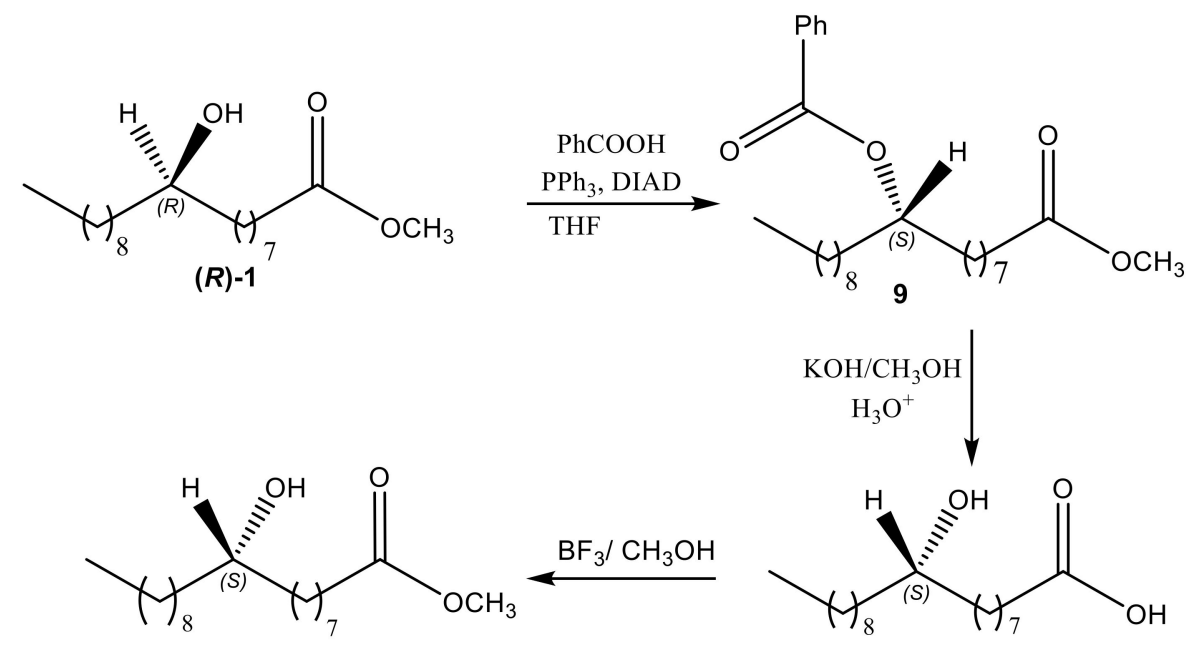

(S)-1

(S)-HSA

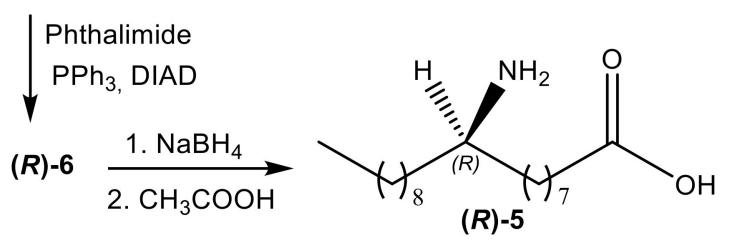

Scheme 4. Synthesis of (S)-1 and (R)-5.

The enantiopurity degree of (S)-1 was measured [11,14] by reacting it with $(R)-(-)-O$-acetylmandelic acid: A diastereomeric ratio $>5 / 95$ between the $(R, R)$ and $(S, R)$ diastereomers was calculated from the ${ }^{1} \mathrm{H}-\mathrm{NMR}$ of the crude reaction mixture. Analogously, the $(R)-5$ enantiopurity degree was evaluated as a 10/90 diastereomeric ratio, by analyzing ${ }^{1} \mathrm{H}-\mathrm{NMR}$ spectrum of the reaction with the acyl chloride of (S)-O-acetylmandelic acid.

\subsection{Biological Activity}

\subsubsection{Preliminary Biological Activity of $(R)-2,3,(S)-4$, and $(S)-5$}

In order to gain information on the effect of the change of the group bound to C-9, preliminary biological tests on $\mathrm{IC}_{50}$ value for compounds $(R)-\mathbf{1},(R)-\mathbf{2}, \mathbf{3},(S)-4$, and $(S)-\mathbf{5}$ were carried out. From the MTT tests, the only active compounds were the methyl ester $(R)-\mathbf{1}$ and the amino derivative (S)-5 (see below). The absence of significant activity in the case of compounds functionalized on C-9 with groups not able to make hydrogen bonds might be considered as a strong indication of the importance of the presence of a group bearing hydrogen atoms bound to a heteroatom on this position. The results obtained with $(R)-\mathbf{1}$ and $(S)-5$ encouraged this study to also synthesize the corresponding enantiomer in order to compare their biological effects.

2.2.2. Effect of Methyl ( $9 R)$-9-hydroxystearate [(R)-1], Methyl (9S)-9-hydroxystearate [(S)-1], Methyl (9R)-9-aminostearate [(R)-5] and Methyl (9S)-9-aminostearate [(S)-5] on Proliferation of HT29

The in vitro $\mathrm{IC}_{50}$ growth inhibitory concentration was determined for $(R)-\mathbf{1},(S)-\mathbf{1},(R)-\mathbf{5}$ and $(S)-\mathbf{5}$, incubating the HT29 with increasing concentrations of the compounds for $24 \mathrm{~h}$. The data obtained from the MTT analyses were examined to assess the concentration of compounds required for $50 \%$ inhibition of cell viability ( $\mathrm{IC}_{50}$ ): The values corresponded to $49 \pm 1.3 \mu \mathrm{M}$ for $(\boldsymbol{R})-\mathbf{1}, 51 \pm 1.1 \mu \mathrm{M}$ for (S)-1, $57 \pm 2.1 \mu \mathrm{M}$ for (R)-5 and $43 \pm 4.5 \mu \mathrm{M}$ for (S)-5 (Figure 3).

The effects on HT29 cell proliferation after treatment with $(\boldsymbol{R})-\mathbf{1}$ and (S)-1 and with $(R)-5$ and (S)-5 are reported in Figure 4 . In panel A, the effects of $49 \mu \mathrm{M}(R)-1$ and $51 \mu \mathrm{M}(S)-1$ are reported. The results for the $(R)-\mathbf{1}$ and $(S)-1$ treatment show a significantly greater effect for the $(R)$-enantiomer, recalling the already reported behavior of the two enantiomers of 9-hydroxystearic acid. In panel B, the effects 
for $(R)-5$ and $(S)-5$ at the respective concentrations of $57 \mu \mathrm{M}$ and $43 \mu \mathrm{M}$ are reported: In this case, after $24 \mathrm{~h}$ of treatment, the cell proliferation strongly reduced, and after $48 \mathrm{~h}$ and $72 \mathrm{~h}$ of treatment, the cell numbers still diminished, indicating a continuous cytotoxic effect.

A

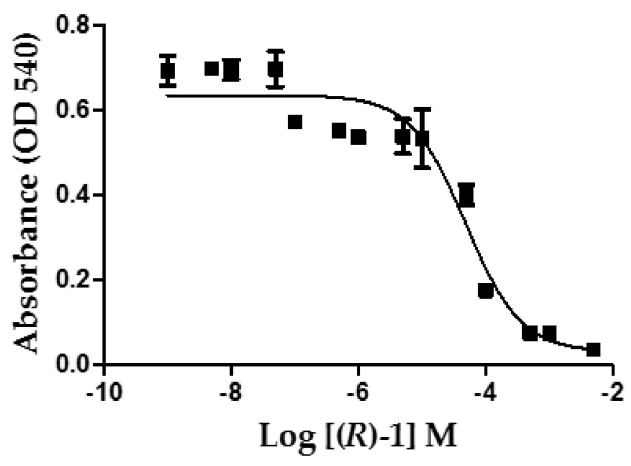

C

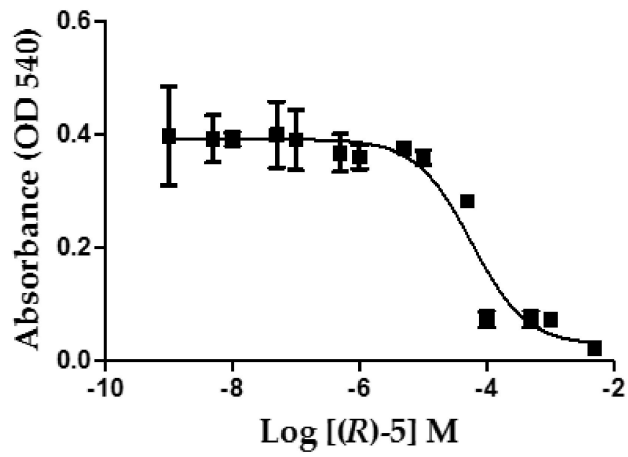

B

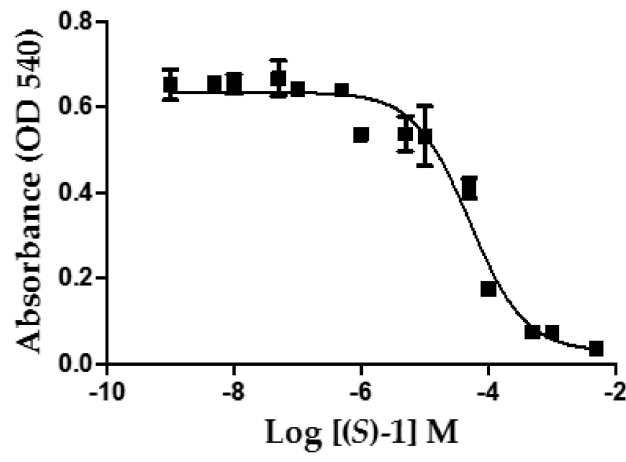

D

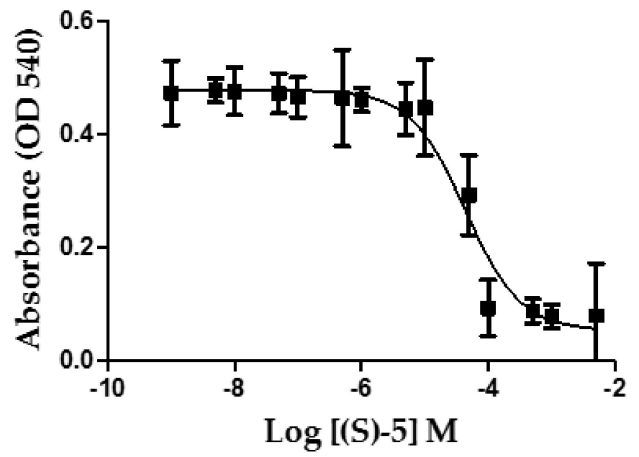

Figure 3. Dose response curves of HT29 cell viability upon treatment with different concentrations of (A) (R)-1, of (B) (S)-1, of (C) (R)-5 and (D) (S)-5.

These findings prompted this study to gain more information on the biological effect of the methyl (9R)-9-hydroxystearate $(\boldsymbol{R})-\mathbf{1}$.

A

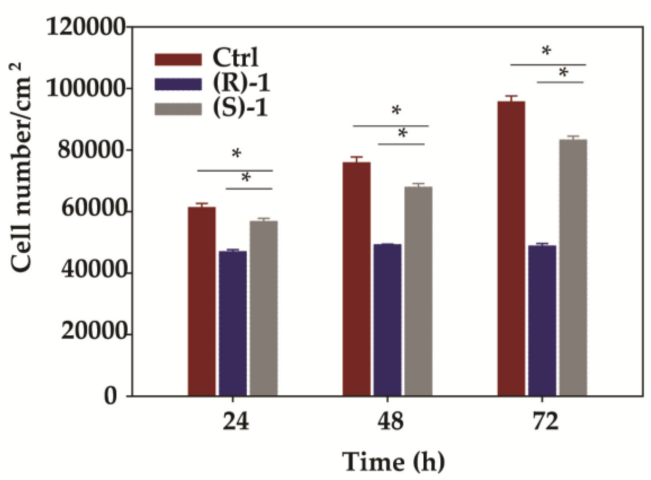

B

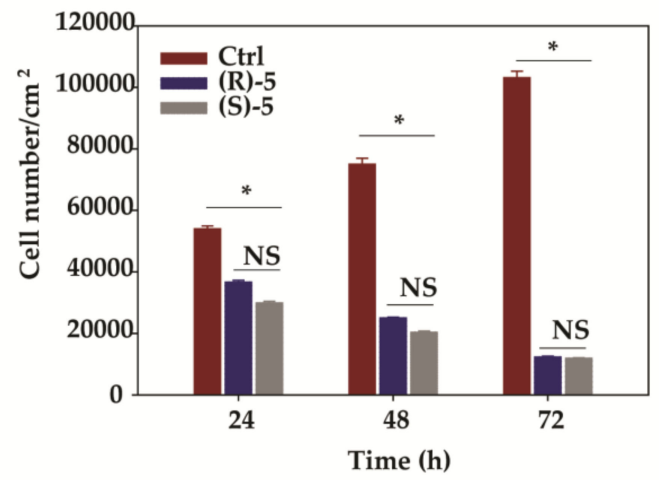

Figure 4. Effects on cell proliferation. (A) Antiproliferative effect of (R)-1 and (S)-1 on HT29 at 24, 48, and $72 \mathrm{~h}$ of treatment as compared with the control. (B) Antiproliferative effect of $(R)-5$ or $(S)-5$ in the same experimental conditions. The analysis was carried out by two-way analysis of variance (ANOVA) followed by the Bonferroni multiple comparisons. The differences of at least $p<0.05$ were considered significant. Statistical analysis was carried out using Prism GraphPad software. 


\subsubsection{Cell Cycle Analysis}

In order to assess whether the antiproliferative effect of $(R)-1$ was associated with the interference of the cell cycle progression, DNA profiles of cultured cells were examined by flow cytometry. The cells were exposed to the compound for $48 \mathrm{~h}$ prior to processing and analysis. As shown in Figure 5, the exposure to $(\boldsymbol{R})-\mathbf{1}$ resulted in an increase in the number of the G0/G1 $(80.18 \pm 0.7 \%$ versus $73.91 \pm 0.9 \%)$ phase, while reducing their number in the $\mathrm{S}(13.18 \pm 0.5 \%$ versus $17.97 \pm 0.2 \%)$ and G2/M (6.64 $\pm 0.2 \%$ versus $8.12 \pm 0.1 \%)$ phases, thus indicating that the treatment leads to a cell cycle arrest. The flow cytometric data correlates with cell counting over time. Indeed, the administration of (R)-1 reduced the number of cells by $23 \%$ at $24 \mathrm{~h}$, by $35 \%$ at $48 \mathrm{~h}$ and by $49 \%$ at 72 from the treatment, indicating that the cells did not duplicate anymore.
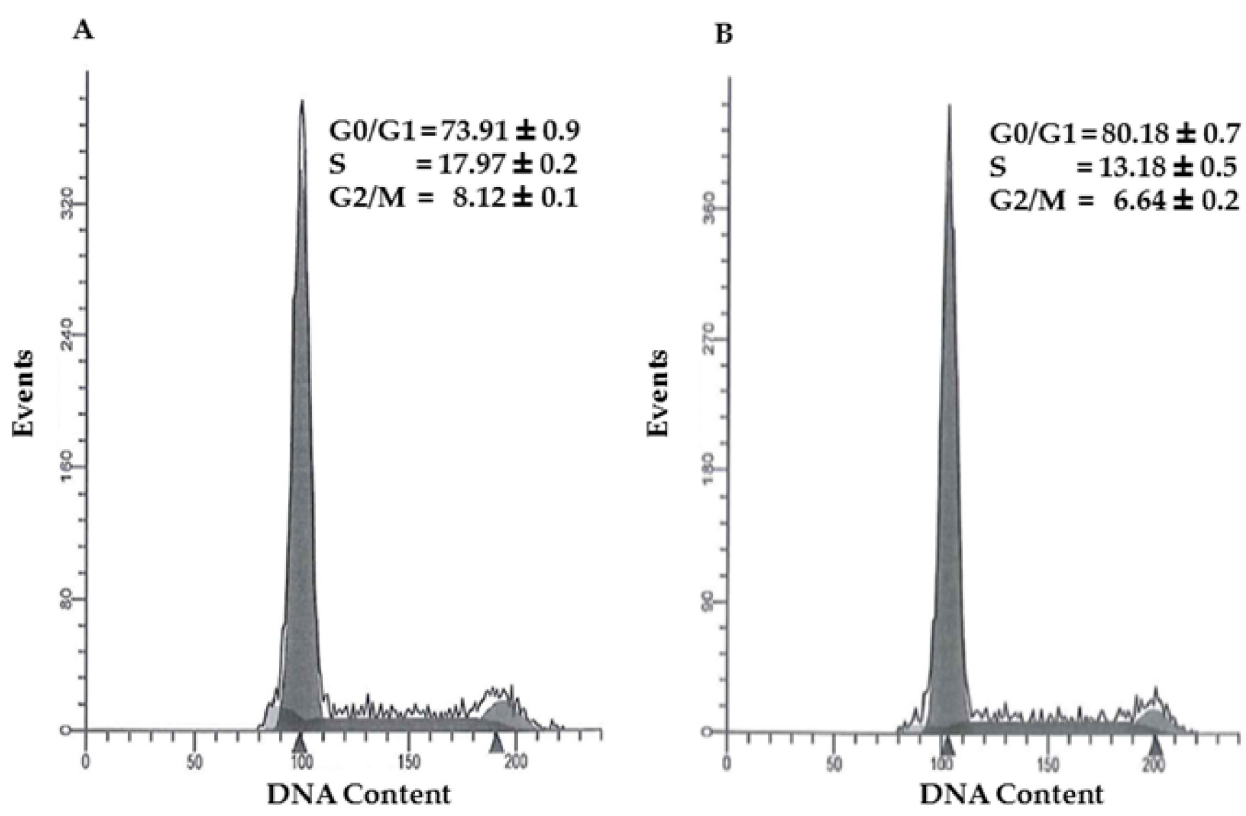

Figure 5. Effect of (R)-1 on cell cycle. The cells were incubated for $48 \mathrm{~h}$ with the vehicle (A) or with $49 \mu \mathrm{M}$ of (R)-1 (B), afterward the cell cycle distribution was determined by flow cytometry. The two panels report the cytofluorimeter outputs obtained in one typical experiment repeated twice with similar results.

\subsubsection{Effect of $(R)-1$ on Histone Acetylation}

Since the above findings parallel those found for the parent (R)-9-HSA [11], an investigation of whether the molecular target might be histone deacetylase, as in the case of 9-HSA, was undertaken.

To identify the state of histones acetylation, these proteins were extracted from the control HT29 and treated for $6 \mathrm{~h}$ with $49 \mu \mathrm{M}$ of $(\boldsymbol{R})$-1. Acetylation was detected by a western blot using an anti-acetyl lysine monoclonal antibody. The histone acetylation signals were quantified by densitometry and normalized on histone H3. As shown in Figure 6, the treatment with $(\boldsymbol{R})-\mathbf{1}$ for $6 \mathrm{~h}$ increased histone H4 acetylation by $50 \%$, while the acetylation status of histones $\mathrm{H} 2 / \mathrm{H} 3$ did not change. 
A

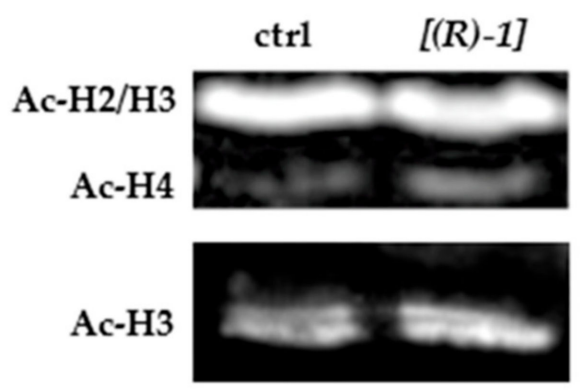

B

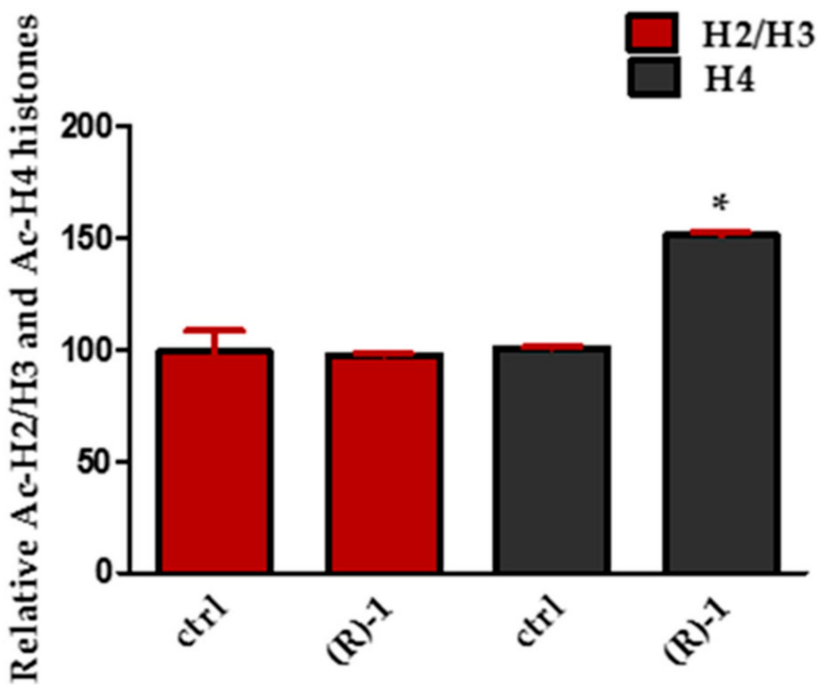

Figure 6. Effect of (R)-1 on histone H4 acetylation. (A) The cells were cultured for $6 \mathrm{~h}$ in the absence (control) or presence of $49 \mu \mathrm{M}(\boldsymbol{R})-1$. The cell nuclear extracts were prepared and subjected to a western blot analysis for acetylated (ac) histone $\mathrm{H} 2 / \mathrm{H} 3$, histone $\mathrm{H} 4$ and histone $\mathrm{H} 3$ as loading controls. (B) A representative experiment, repeated three times with similar results and densitometric analysis of the bands (mean $\pm \mathrm{SEM} ; n=3$ ), are shown. ${ }^{*} p<0.05$.

\subsection{5. (R)-1 Induces Gene and Relative Protein Expression Modulations}

The induction of p21 is one of the common phenomena observed after treatment with HDAC inhibitors such as TSA, NaBu, SAHA or 9-HSA [7,15-17]. Myc is a transcription factor whose activity is causally involved in cancers, principally through its capacity to drive tumor cell proliferation and promote angiogenesis, invasion, and metastasis [18-21]. The downregulation of Myc is an essential part of the anti-proliferative response to differentiation signals. Thus, a western blot analysis was performed to assess the expression of p21 and Myc in HT29 cells after (R)-1 treatment. As expected, p21 was induced by the treatment with $(R)-\mathbf{1}$ compared to its expression level in the untreated control cells, while the Myc expression decreased significantly by $(R)-\mathbf{1}$ treatment (Figure 7A,B).

The observed cytostatic effects of $(\boldsymbol{R})-\mathbf{1}$ transcription levels of P21 and MYCBP (MYC) were analysed by quantitative Real Time-Polymerase Chain Reaction (RT-PCR. The genes were analysed after $6 \mathrm{~h}$ of treatment. The qRT-PCR was performed on cDNA of the control and (R)-1-treated cells, and the $\Delta \Delta \mathrm{C}_{\mathrm{T}}$ method was used with the GAPDH gene as the housekeeping gene. The relative transcription levels, expressed as a means of fold changes, are reported in Figure 7C. $(R)-\mathbf{1}$ administration transcription significantly increases P21 gene at $6 \mathrm{~h}$ of treatment, while MYC is significantly reduced. 
A

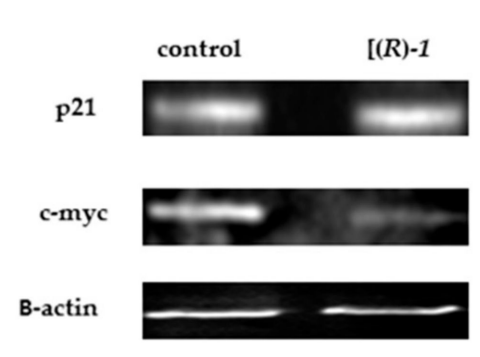

C

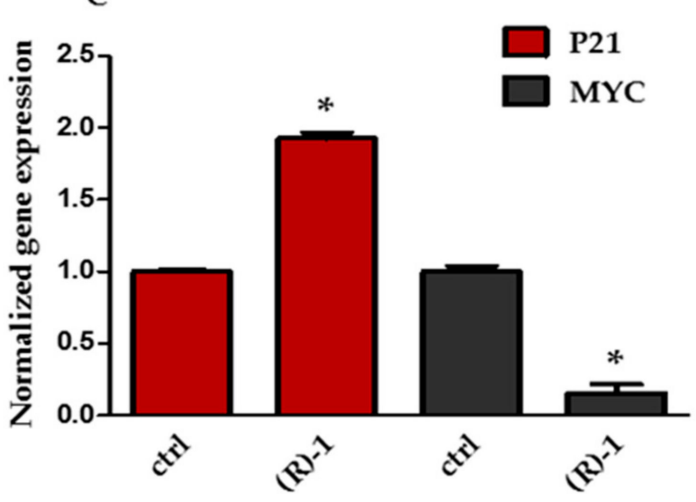

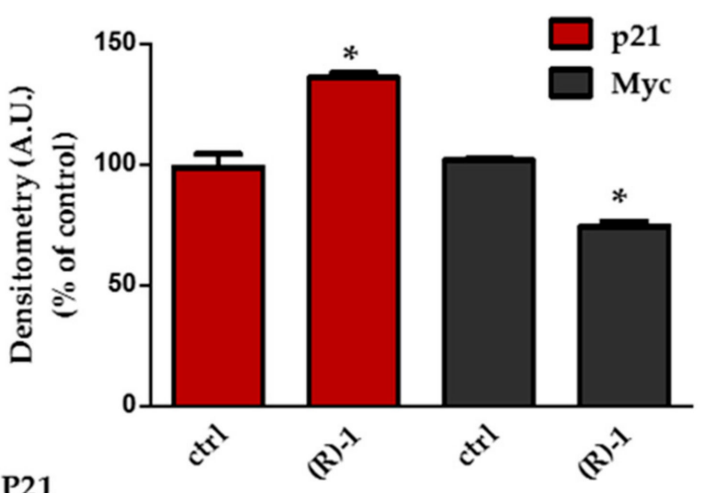

Figure 7. The effects of $(\boldsymbol{R})-\mathbf{1}$ on the expression of cell growth regulatory genes and proteins in HT29 colon cancer cell line. A) Representative western blots for p21 and MYC in HT29 cells following $6 \mathrm{~h}$ treatment with $(\boldsymbol{R})-\mathbf{1}$. $\beta$-actin was used as the control. B) Densitometry from western blots for HT29 following $6 \mathrm{~h}$ treatment with (R)-1. Protein quantification was normalized to the $\beta$-actin band. The mean \pm SEM, $n=3$, and ${ }^{*} p<0.05$. C) Changes in mRNA expression of P21 and MYC. GAPDH were used as a control gene. CT values were obtained, the data was normalized against GAPDH and the fold change was calculated by $\triangle \mathrm{CT}$ method. The data are the mean $\pm \mathrm{SEM}$ of three independent experiments. ${ }^{*} p<0.05$.

\section{Materials and Methods}

\subsection{Chemical Syntheses}

Dimorphotheca sinuata L. seeds were bought from Galassi Sementi Srl (Gambettola, FC, Italy). The reagents used, unless stated otherwise, were purchased from Sigma-Aldrich (Milan, Italy). For flash chromatography (FC), silica gel 0.037-0.063 mm (Merck KGaA, Darmstadt, Germany) was used as the stationary phase. Thin layer chromatography (TLC) was carried out on silica gel 60 (Fluka Analytical, Buchs, Switzerland) and the spots were revealed, depending on the compound to be analyzed, using UV light, and an aqueous solution of $\left(\mathrm{NH}_{4}\right)_{6} \mathrm{MoO}_{24}(2.5 \%)$ and $\left(\mathrm{NH}_{4}\right)_{4} \mathrm{Ce}\left(\mathrm{SO}_{4}\right)_{4}(4 \%)$ in $10 \% \mathrm{H}_{2} \mathrm{SO}_{4}$, a solution of ninhydrin $0.013 \mathrm{M}$ in $n$-butanol/acetic acid, or a basic solution of potassium permanganate. Anhydrous THF was freshy distilled over sodium benzophenone ketyl. Pyridine, trimethylamine and methanol were dried by standard methods. The hydrogenation was carried out on a Parr hydrogenator model 3911EKX at a hydrogen gas pressure of approximately 40 psi. The nuclear magnetic resonance spectra $\left({ }^{1} \mathrm{H}-\mathrm{NMR}{ }^{13} \mathrm{C}-\mathrm{NMR}\right.$, ) were recorded at $25{ }^{\circ} \mathrm{C}$ on Varian spectrometers Gemini 300 , Mercury 400, or Inova 600 (Varian, Palo Alto, CA, USA). The signal multiplicities were established by DEPT-135 experiments. The chemical shifts were referenced to the solvent $\left(\mathrm{CDCl}_{3}, \delta=7.27\right.$ and $77.0 \mathrm{ppm}$ for ${ }^{1} \mathrm{H}$ and ${ }^{13} \mathrm{C}-\mathrm{NMR}$, respectively). The GC-MS analyses were carried out by gas chromatograph directly interfaced with a mass selective detector (injection temperature: $250{ }^{\circ} \mathrm{C}$; oven temperature was programmed as follows: $60{ }^{\circ} \mathrm{C}$ for $2 \mathrm{~min}$, increased up to $260^{\circ} \mathrm{C}$ at the rate of $20^{\circ} / \mathrm{min}$, followed by $260{ }^{\circ} \mathrm{C}$ for $20 \mathrm{~min}$; the carrier gas was helium, used at a flow rate of $1 \mathrm{~mL}$; the transfer line temperature 
was $280^{\circ} \mathrm{C}$; the ionization was obtained by electron impact (EI); the acquisition range was $50-500 \mathrm{~m} / \mathrm{z}$ ). The ESI-MS spectra were recorded using a Waters 2Q 4000 instrument (Waters Corporation, Milford, MA, USA). The melting points were measured on a Büchi apparatus (Stone, Staffs, UK) and were not corrected. The Fourier transform infrared (FT-IR) spectra of the organic compounds were recorded using a Perkin-Elmer FT-IR MOD 1600 spectrophotometer (Norwalk, CT, USA).

\subsubsection{Synthesis of Methyl (9R)-9-hydroxyoctadecanoate [(R)-1]}

Dimorphotheca sinuata L. seeds (12.0 g) were ground and suspended in a $\mathrm{CHCl}_{3} / \mathrm{MeOH}$ mixture $(2: 1 \mathrm{v} / \mathrm{v}, 200 \mathrm{~mL})$ and the mixture was kept under nitrogen atmosphere, in the dark, and stirred for $24 \mathrm{~h}$. After filtration and washing of the solid with $\mathrm{CHCl}_{3}(3 \times 20 \mathrm{~mL}), 20 \mathrm{~mL}$ of $0.1 \mathrm{M} \mathrm{HCl}$ and $0.1 \mathrm{M}$ $\mathrm{NaCl}$ aqueous solution was added to the green solution. After extraction with $\mathrm{CHCl}_{3}(3 \times 15 \mathrm{~mL})$, the combined organic layers were dried over anhydrous $\mathrm{MgSO}_{4}$. After filtration and solvent removal in vacuo at $30^{\circ} \mathrm{C}, 4.0 \mathrm{~g}$ of residue was recovered. The crude yellow oil was dissolved in $\mathrm{CH}_{3} \mathrm{OH}$ $(40 \mathrm{~mL})$ under nitrogen atmosphere and the solution was kept at $0{ }^{\circ} \mathrm{C}$ by immersion in an external water/ice bath. Then, $\mathrm{CH}_{3} \mathrm{ONa}(2.16 \mathrm{~g})$ was added and the mixture was magnetically stirred at $0{ }^{\circ} \mathrm{C}$ for $2 \mathrm{~h}$. The mixture was acidified to $\mathrm{pH} 4.0$ and extracted with $n$-hexane $(3 \times 20 \mathrm{~mL})$. The combined organic layers were dried over anhydrous $\mathrm{MgSO}_{4}$. After filtration, the solvent was removed under reduced pressure and the residue $(2.2 \mathrm{~g})$ dissolved in $10 \mathrm{~mL}$ of ethyl acetate and transferred into the hydrogenation vessel. A catalytic amount of $\mathrm{PtO}_{2}$ (Adam's catalyst) was added and the mixture was subjected to hydrogenation ( $40 \mathrm{psi} \mathrm{H}_{2}$ pressure). The reaction course was monitored by ${ }^{1} \mathrm{H}-\mathrm{NMR}$ spectroscopy. Usually, the hydrogenation is complete after approximately $40 \mathrm{~min}$. The mixture was then filtered over celite and the solution concentrated under vacuum. Flash chromatography (eluent: petroleum ether/diethyl ether 7/3) of the residue gave methyl (9R)-9-hydroxyoctadecanoate [(R)-1] $\left(\mathrm{C}_{19} \mathrm{H}_{38} \mathrm{O}_{3}\right)$ as a white solid $(0.74 \mathrm{~g})$, m.p.: $50-51^{\circ} \mathrm{C}$ (Lit. [22]: 50-51.5 $\left.{ }^{\circ} \mathrm{C}\right) .{ }^{1} \mathrm{H}-\mathrm{NMR}\left(600 \mathrm{MHz}, \mathrm{CDCl}_{3}\right)$ : $\delta(\mathrm{ppm})=3.67\left(\mathrm{~s}, 3 \mathrm{H}, \mathrm{OCH}_{3}\right), 3.61-3.55(\mathrm{~m}, 1 \mathrm{H}, \mathrm{CHOH}), 2.30\left(\mathrm{t}, 2 \mathrm{H}, J=7.6 \mathrm{~Hz}, \mathrm{CH}_{2} \mathrm{COO}\right), 1.62$ (quint, $\left.2 \mathrm{H}, J=7.4 \mathrm{~Hz}, \mathrm{CH}_{2} \mathrm{CH}_{2} \mathrm{COO}\right), 1.48-1.21(\mathrm{~m}, 27 \mathrm{H}$, incl. $\mathrm{OH}), 0.88\left(\mathrm{t}, 3 \mathrm{H}, J=7.0 \mathrm{~Hz}_{2} \mathrm{CH}_{3}\right.$ ). ${ }^{13} \mathrm{C}-\mathrm{NMR}\left(100.6 \mathrm{MHz}, \mathrm{CDCl}_{3}\right) \delta(\mathrm{ppm})=174.1,71.7,51.3,37.4,37.3,33.9,31.8,29.6,29.56,29.5,29.4$, 29.2, 29.1, 28.9, 25.5, 25.4, 24.8, 22.6, 14.05. IR $\left(\mathrm{CHCl}_{3}\right): 3427,1728 \mathrm{~cm}^{-1}$. MS (EI) m/z (\%): $283\left(\mathrm{M}^{+}{ }_{-}\right.$ $\left.\mathrm{OCH}_{3}, 2\right), 264$ (4), 187(45), 159 (11), 158 (53), 155 (100), 129 (6), 115 (18), 109 (14), 87 (50), 74 (33), 69 (18), 55 (31). The enantiomeric excess was determined by derivatization with $(R)-(-)-O$-acetyl mandelic acid as previously reported $[12,14]$ and was found to be $80 \%$.

\subsubsection{Synthesis of Methyl (R)-9-(tosyloxy)octadecanoate [(R)-2]}

Methyl (9R)-9-Hydroxyoctadecanoate [(R)-1, $0.190 \mathrm{~g}(0.60 \mathrm{mmol}], 0.607 \mathrm{~g}(3.18 \mathrm{mmol}) \mathrm{of} \mathrm{TsCl}$ and $10 \mathrm{~mL}$ of anhydrous pyridine were kept at $0{ }^{\circ} \mathrm{C}$ for $1 \mathrm{~h}$ then at $4{ }^{\circ} \mathrm{C}$. The reaction was monitored by TLC ( $n$-hexane/AcOEt $1: 1, \mathrm{R}_{\mathrm{F}}=0.54$ ) and, when it was complete (after approximately 5 days), it was quenched with water $(40 \mathrm{~mL})$. The mixture was extracted with $\mathrm{Et}_{2} \mathrm{O}$ and the combined organic layers were acidified with $\mathrm{HCl} 1 \mathrm{M}$. The organic layer was dried over anhydrous $\mathrm{MgSO}_{4}$, filtered and concentrated under reduced pressure. Compound $(R)-2\left(\mathrm{C}_{26} \mathrm{H}_{44} \mathrm{O}_{5 \mathrm{~S}}\right)$ was obtained as colorless oil in $70 \%$ yield. ${ }^{1} \mathrm{H}-\mathrm{NMR}\left(300 \mathrm{MHz} \mathrm{CDCl}_{3}\right): \delta(\mathrm{ppm})=0.87\left(\mathrm{t}, J=6.9 \mathrm{~Hz}, 3 \mathrm{H}, \mathrm{CH}_{3}\right), 1.13-1.30(\mathrm{~m}, 27$ $\left.\mathrm{H},\left(\mathrm{CH}_{2}\right)_{13}\right), 1.55\left(\mathrm{~m}, 2 \mathrm{H}, \mathrm{CH}_{2} \mathrm{CH}_{2} \mathrm{COOCH}_{3}\right), 2.27\left(\mathrm{t}, J=7.56 \mathrm{~Hz}, 2 \mathrm{H}, \mathrm{CH}_{2} \mathrm{COOCH}_{3}\right), 2.42(\mathrm{~s}, 3 \mathrm{H}$, $\left.\mathrm{PhCH}_{3}\right), 3.65\left(\mathrm{~s}, 3 \mathrm{H}, \mathrm{COOCH}_{3}\right), 4.52\left(\mathrm{q}, \mathrm{J}=6.1 \mathrm{~Hz}, 1 \mathrm{H} \mathrm{CHOSO}_{2}\right), 7.31(\mathrm{~d}, 2 \mathrm{H}, \mathrm{J}=4 \mathrm{~Hz}$, phenyl), 7.77 $\left(\mathrm{d}, J=4.4 \mathrm{~Hz}, 2 \mathrm{H}\right.$, phenyl). ${ }^{13} \mathrm{C}-\mathrm{NMR}\left(75.44 \mathrm{MHz}, \mathrm{CDCl}_{3}\right): \delta(\mathrm{ppm})=174.3,144.3,134.8,129.6,127.7$, 84.5, 51.4, 34.1 (two signals overlapped), 34.0, 31.9, 29.43, 29.38, 29.3(two signals overlapped), 29.1, 29.0, $28.9,24.8,24.7,24.6,22.6,21.6,14.1$. ESI-MS $(m / z): 481[\mathrm{M}+\mathrm{Na}]^{+}, 469[\mathrm{M}+\mathrm{H}]^{+}$

\subsubsection{Synthesis of Methyl 9-MethoxyOctadecanoate (3)}

Compound (R)-2 (0.167 g, $0.357 \mathrm{mmol})$ was dissolved in $\mathrm{CH}_{3} \mathrm{OH}(5 \mathrm{~mL})$ and the solution was refluxed for $7 \mathrm{~h}$. After removal of the solvent under reduced pressure, brine $(20 \mathrm{~mL}) \mathrm{was}$ added and the mixture was extracted with $\mathrm{Et}_{2} \mathrm{O}(4 \times 20 \mathrm{~mL})$. The combined organic layers were dried over anhydrous 
$\mathrm{MgSO}_{4}$. After filtration and concentration, the residue was purified by FC (eluent: $n$-hexane/ $\mathrm{CH}_{2} \mathrm{Cl}_{2}$ from 6:4 to 1:1 to 3:7 to 2:8 until $\left.\mathrm{CH}_{2} \mathrm{Cl}_{2}\right)$. Pure methyl 9-methoxyoctadecanoate $\left(3,\left(\mathrm{C}_{20} \mathrm{H}_{40} \mathrm{O}_{3}\right)\right.$ was obtained in 55\% (0.064 g, $0.195 \mathrm{mmol}) .{ }^{1} \mathrm{H}-\mathrm{NMR}\left(300 \mathrm{MHz}, \mathrm{CDCl}_{3}\right): \delta(\mathrm{ppm})=0.86(\mathrm{t}, J=6.9 \mathrm{~Hz}$, $\left.3 \mathrm{H}, \mathrm{CH}_{3}\right), 1.24-1.32\left(\mathrm{~m}, 27 \mathrm{H},\left(\mathrm{CH}_{2}\right)_{13}\right), 1.60\left(\mathrm{~m}, 2 \mathrm{H}, \mathrm{CH}_{2} \mathrm{CH}_{2} \mathrm{COOCH}_{3}\right), 2.29(\mathrm{t}, J=7.49 \mathrm{~Hz}, 2 \mathrm{H}$, $\left.\mathrm{CH}_{2} \mathrm{COOCH} 3\right), 3.10\left(\mathrm{~m}, 1 \mathrm{H}, \mathrm{CHOCH}_{3}\right), 3.30\left(\mathrm{~s}, 3 \mathrm{H}, \mathrm{CHOCH}_{3}\right), 3.65\left(\mathrm{~s}, 3 \mathrm{H}, \mathrm{COOCH}_{3}\right) .{ }^{13} \mathrm{C}-\mathrm{NMR}$ $\left(150.80 \mathrm{MHz}, \mathrm{CDCl}_{3}\right): \delta(\mathrm{ppm})=174.3,80.9,56.3,51.4,34.1,33.42,33.41,31.9,29.9,29.66,29.65,29.58$, 29.3, 29.2, 29.1, 25.3, 25.26, 24.9, 22.7, 14.1. MS (EI) $m / z(\%): 327$ ( $\left.\mathrm{M}^{+}-1,0.5\right) 297$ (3), 264 (14), 222 (6), 201 (100), 171 (50), 137 (29), 123 (8), 109 (19), 97 (43), 83 (72), 69 (57), 55 (83).

\subsubsection{Synthesis of Methyl (9S)-9-azidooctadecanoate [(S)-4]}

Method 1:

Compounds $(\boldsymbol{R})-2(0.147 \mathrm{~g}, 0.314 \mathrm{mmol}), \mathrm{NaN}_{3}(0.102 \mathrm{~g}, 1.57 \mathrm{mmol})$, and DMF $(10 \mathrm{~mL})$ were heated at reflux for $3 \mathrm{~h}$. The mixture was treated once with brine $(20 \mathrm{~mL})$ then extracted with $\mathrm{Et}_{2} \mathrm{O}(3 \times 15 \mathrm{~mL})$, then two folds with water $(30 \mathrm{~mL}$ and $50 \mathrm{~mL})$ and each time extracted with $\mathrm{Et}_{2} \mathrm{O}(3 \times 15 \mathrm{~mL})$, finally with brine $(20 \mathrm{~mL})$ then extracted with $\mathrm{Et}_{2} \mathrm{O}(3 \times 15 \mathrm{~mL})$. Each time the organic layer was dried over anhydrous $\mathrm{MgSO}_{4}$ and filtered: The absence of DMF was checked. The combined organic layers were concentrated and the residue chromatographed on silica gel (eluent: 7:3n-hexane/AcOEt). Compound (S) $-4\left(\mathrm{C}_{19} \mathrm{H}_{37} \mathrm{~N}_{3} \mathrm{O}_{2}, 0.064 \mathrm{~g}, 58 \%\right)$ was recovered as colorless oil. ${ }^{1} \mathrm{H}-\mathrm{NMR}\left(300 \mathrm{MHz}, \mathrm{CDCl}_{3}\right): \delta(\mathrm{ppm})$ $=0.88\left(\mathrm{t}, J=6.6 \mathrm{~Hz}, 3 \mathrm{H}, \mathrm{CH}_{3}\right), 1.24-1.33\left(\mathrm{~m}, 26 \mathrm{H},\left(\mathrm{CH}_{2}\right)_{13}\right), 1.61\left(\mathrm{~m}, 2 \mathrm{H}, \mathrm{CH}_{2} \mathrm{CH}_{2} \mathrm{COOCH}_{3}\right), 2.30$ $\left(\mathrm{t}, J=7.9 \mathrm{~Hz}, 2 \mathrm{H}, \mathrm{CH}_{2} \mathrm{COOCH}_{3}\right), 3.21\left(\mathrm{q}, J=6.1 \mathrm{~Hz}, 1 \mathrm{H}, \mathrm{CHN}_{3}\right), 3.65\left(\mathrm{~s}, 3 \mathrm{H}, \mathrm{COOCH}_{3}\right) .{ }^{13} \mathrm{C}-\mathrm{NMR}$ $\left(150.80 \mathrm{MHz}, \mathrm{CDCl}_{3}\right): \delta(\mathrm{ppm})=174.3,63.1,51.4,34.4,34.3,34.0,31.9,30.3,29.5,29.4,29.3,29.2,29.1$, 29.0, 26.1, 26.0, 24.9, 22.6, 14.1; IR-Neat $\left(\mathrm{cm}^{-1}\right)$ : 2928.0, 2856.0, 2361.2, 2098.7, 1742.6, 1465.4, 1257.5, 1171.1; ESI-MS $(\mathrm{m} / \mathrm{z}): 352[\mathrm{M}+\mathrm{Na}]^{+}, 340[\mathrm{M}+\mathrm{H}]^{+}$

Method 2:

Compound $(\boldsymbol{R})-\mathbf{1}(0.230 \mathrm{~g}, 0.732 \mathrm{mmol})$ was dissolved in anhydrous THF $(7.5 \mathrm{~mL})$ and under nitrogen atmosphere. $\mathrm{PPh}_{3}(0.398 \mathrm{~g}, 1.52 \mathrm{mmol})$ and DIAD $94 \%(300 \mu \mathrm{L}, 1.52 \mathrm{mmol})$ were added and the yellow mixture was stirred. After a few minutes, DPPA $97 \%(330 \mu \mathrm{L}, 1.52 \mathrm{mmol})$ was added. The solution became cloudy and after $18 \mathrm{~h}$, had come clear. The crude was subjected to FC (eluent: $n$-hexane/AcOEt 9:1) and pure (S)-4 (0.190 g, 77\%) was recovered.

\subsubsection{Synthesis of Methyl (9S)-9-aminooctadecanoate [(S)-5]}

Compound $(\boldsymbol{R})-\mathbf{1}(0.222 \mathrm{~g}, 0.70 \mathrm{mmol})$ was dissolved in anhydrous THF $(8.0 \mathrm{~mL})$ in a flame dried apparatus immersed in an ice-bath and kept under nitrogen atmosphere. $\mathrm{PPh}_{3}(0.103 \mathrm{~g}$ $(0,70 \mathrm{mmol})$ and phthalimide $(0.103 \mathrm{~g}(0,70 \mathrm{mmol})$ were added. Through a funnel, DIAD $(0.2 \mathrm{~mL}$, $0.70 \mathrm{mmol}$ ) in $2.0 \mathrm{~mL}$ of THF was added dropwise. After $12 \mathrm{~h}$, the reaction appeared complete (TLC: petroleum light/diethyl ether 6:4). The reaction mixture was concentrated. FC on silica gel (light petroleum/diethyl ether: 20:1) of the residue gave $0.280 \mathrm{~g}(0.63 \mathrm{mmol}, 90 \%$ yield $)$ of the intermediate (9S)-9-(1,3-dioxo-1,3-dihydro-2H-isoindol-2-yl) octadecanoate [(S)-6] $\left(\mathrm{C}_{27} \mathrm{H}_{41} \mathrm{NO}_{4}\right)$ as a colorless oil:

${ }^{1} \mathrm{H}-\mathrm{NMR}\left(400 \mathrm{MHz}, \mathrm{CDCl}_{3}\right), \delta(\mathrm{ppm})=7.83-7.79(\mathrm{~m}, 2 \mathrm{H}), 7.71-7.68(\mathrm{~m}, 2 \mathrm{H}), 4.26-4.06(\mathrm{~m}, 1 \mathrm{H})$, $3.63\left(\mathrm{~s}, 3 \mathrm{H}, \mathrm{OCH}_{3}\right), 2.25(\mathrm{t}, J=7.43 \mathrm{~Hz}, 2 \mathrm{H}), 2.11-1.97(\mathrm{~m}, 2 \mathrm{H}), 1.74-1.61(\mathrm{~m}, 2 \mathrm{H}), 1.61-1.49(\mathrm{~m}, 2$ $\mathrm{H}), 1.32-1.14(\mathrm{~m}, 22 \mathrm{H}), 0.84\left(\mathrm{t}, J=6.97 \mathrm{~Hz}, 3 \mathrm{H}, \mathrm{CH}_{3}\right) .{ }^{13} \mathrm{C}-\mathrm{NMR}\left(100.56 \mathrm{MHz}, \mathrm{CDCl}_{3}\right), \delta(\mathrm{ppm})=$ 174.2, 168.8, 133.8, 131.8, 123.0, 52.2, 51.4, 34.0, 32.5, 32.4, 31.8, 29.45, 29.43, 29.23, 29.21, 29.04 (2 signals overlapped), 29.0, 26.6, 26.5, 24.8, 22.6, 14.1. ESI-MS (m/z): $444[\mathrm{M}+\mathrm{H}]^{+}$.

Sodium borohydride $(0.06 \mathrm{~g}, 1.6 \mathrm{mmol})$ in 2-propanol $(3.0 \mathrm{~mL})$ was added to a solution of the compound $(S)-6(0.131 \mathrm{~g}, 0.29 \mathrm{mmol})$ and the mixture was magnetically stirred at room temperature for $12 \mathrm{~h}$. Glacial acetic acid $(0.3 \mathrm{~mL})$ was added and the mixture was heated at $80{ }^{\circ} \mathrm{C}$ for $2 \mathrm{~h}$. After concentration, water $(5 \mathrm{~mL})$, and then saturated aqueous solution of $\mathrm{NaHCO}_{3}(5 \mathrm{~mL})$ were added. After extraction with ethyl acetate $(3 \times 10 \mathrm{~mL})$, the combined organic layer was dried over anhydrous magnesium sulfate. After filtration and removal of the solvent under reduced pressure, the crude was subjected to FC (eluent: $\mathrm{CH}_{2} \mathrm{Cl}_{2} / \mathrm{CH}_{3} \mathrm{OH} 10 / 1$ ), the spots being evidenced with ninhydrin stain. 
Compound $(S)-5(0.027 \mathrm{~g}, 0.09 \mathrm{mmol})$ was obtained in a 30\% yield. An alternative method was as follows: Hydrazine hydrate $(0.16 \mathrm{~mL}, 3.2 \mathrm{mmol})$ was added to a solution of compound (S)-6 (0.280 g, $0.63 \mathrm{mmol}$ ) in ethanol $(5 \mathrm{~mL})$ and the mixture was heated and refluxed for $3 \mathrm{~h}$. The formation of a white solid was observed. After cooling, $1 \mathrm{M} \mathrm{HCl}$ was added until $\mathrm{pH}=6$. Then, the solution was filtered on a Buchner funnel. The mixture was treated with saturated solution of $\mathrm{NaHCO}_{3}$ until reaching $\mathrm{pH} \sim 9$ and then it was extracted with $\mathrm{CH}_{2} \mathrm{Cl}_{2}(4 \times 10 \mathrm{~mL})$ and dried over anhydrous $\mathrm{MgSO}_{4}$. After filtration and removal of the solvent under reduced pressure, the light yellow oil was subjected to FC (eluent: $\left.\mathrm{CH}_{2} \mathrm{Cl}_{2} / \mathrm{CH}_{3} \mathrm{OH} 10 / 1\right)$, obtaining the product in $28 \%$ yield. Compound $(S)-5\left(\mathrm{C}_{19} \mathrm{H}_{39} \mathrm{NO}_{2}\right):{ }^{1} \mathrm{H}-\mathrm{NMR}$ $\left(400 \mathrm{MHz}, \mathrm{CDCl}_{3}\right): \delta(\mathrm{ppm})=0.88\left(\mathrm{t}, J=6.9 \mathrm{~Hz}, 3 \mathrm{H}, \mathrm{CH}_{3}\right), 1.24-1.32\left(\mathrm{~m}, 26 \mathrm{H},\left(\mathrm{CH}_{2}\right)_{13}\right), 1.58-1.65(\mathrm{~m}$, $\left.2 \mathrm{H}, \mathrm{CH}_{2} \mathrm{CH}_{2} \mathrm{COOCH}_{3}\right), 2.29\left(\mathrm{t}, J=7.7 \mathrm{~Hz}, 2 \mathrm{H}, \mathrm{CH}_{2} \mathrm{COOCH}_{3}\right), 3.13\left(\mathrm{~m}, 1 \mathrm{H}, \mathrm{CHNH}_{2}\right), 3.66(\mathrm{~s}, 3 \mathrm{H}$, $\left.\mathrm{COOCH}_{3}\right), 8.30$ (br.s, $\left.2 \mathrm{H}, \mathrm{NH}_{2}\right) .{ }^{13} \mathrm{C}-\mathrm{NMR}\left(100.56 \mathrm{MHz} \mathrm{CDCl}_{3}\right): \delta(\mathrm{ppm})=174.2,51.6,51.4,35.92$, 35.86, 34.0, 31.9, 29.63, 29.55 (two signals overlapped), 29.4, 29.3, 29.12, 29.06, 25.8, 25.7, 24.9, 22.6, 14.1. MS (m/z): 282 (5), 267(1), 250(1), 207(3), 186(100), 156(99), 109(4), 97(2), 83(4), 70(5), 56(11). ESI-MS $(\mathrm{m} / \mathrm{z}): 336[\mathrm{M}+\mathrm{Na}]^{+}, 314[\mathrm{M}+\mathrm{H}]^{+} ; \mathrm{IR}\left(\mathrm{cm}^{-1}\right): 3423.5,2950.0,2870.0,1710,1635.8$.

The synthesis of $(\boldsymbol{R})-\mathbf{5}$ was carried out with the same procedure starting from (S)-1.

\subsubsection{Synthesis of (S)-2-Chloro-2-oxo-1-phenylethyl Methyl Carbonate (7)}

In a flame-dried apparatus and under nitrogen atmosphere, (S)-O-acetylmandelic acid (1.046 g, 5,4 mmol $)$ and anhydrous $\mathrm{CH}_{2} \mathrm{Cl}_{2}(10 \mathrm{~mL})$ were added. To the solution, oxalyl chloride $(0.47 \mathrm{~mL}$, $5.4 \mathrm{mmol}$ ) dissolved in anhydrous $\mathrm{CH}_{2} \mathrm{Cl}_{2}(2 \mathrm{~mL})$ were added dropwise. After $2 \mathrm{~h}$ at room temperature and under magnetic stirring, the solvent was distilled at room pressure. The residue was distilled at $0.01 \mathrm{mmHg}$ and the colorless oil with b.p. $=102-103{ }^{\circ} \mathrm{C}$ found to be compound $7\left(\mathrm{C}_{10} \mathrm{H}_{9} \mathrm{ClO}_{4}\right)$.

${ }^{1} \mathrm{H}-\mathrm{NMR}\left(300 \mathrm{MHz}, \mathrm{CDCl}_{3}\right), \delta(\mathrm{ppm}): 7.59-7.37(\mathrm{~m}, 5 \mathrm{H}), 6.09$ (s, $\left.1 \mathrm{H}\right), 2.22(\mathrm{~s}, 3 \mathrm{H}) .{ }^{13} \mathrm{C}-\mathrm{NMR}$ (75.44 MHz, $\left.\mathrm{CDCl}_{3}\right), \delta$ (ppm): 170.7, 169.8, 130.8, 130.2, 129.2, 128.4, 80.8, 20.4.

3.1.7. Methyl (9S)-9-\{[(2S)-2-(Acetyloxy)-2-Phenylacetyl]amino\}octadecanoate [(S,S)-8] and Methyl $(9 R)-9-\{[(2 S)-2-($ Acetyloxy)-2-Phenylacetyl]amino\}octadecanoate $[(R, S)-8]$

The optical purity of (S)-5 was determined by ${ }^{1} \mathrm{H}-\mathrm{NMR}$ analysis after derivatization with 7 , the acyl chloride of the (S)-(-)-O-acetylmandelic acid. Compound $7(2.8 \mathrm{mg})$ in $0.5 \mathrm{~mL}$ of $\mathrm{CD}_{2} \mathrm{Cl}_{2}$ was put directly into the NMR spectroscopy tube and methyl 9(S)-9-aminostearate [(S)-5] (4 mg, $0.013 \mathrm{mmol})$ dissolved in $\mathrm{CD}_{2} \mathrm{Cl}_{2}(0.5 \mathrm{~mL})$ was added. Then, triethylamine $(2.7 \mu \mathrm{L})$ was added and the ${ }^{1} \mathrm{H}-\mathrm{NMR}$ spectrum of the crude was recorded. A diastereomeric ratio of $\sim 9: 1$ between methyl (9S)-9-\{[(2S)-2-(acetyloxy)-2-phenylacetyl]amino\}octadecanoate and methyl (9R)-9-\{[(2S)2-(acetyloxy)-2-phenylacetyl]amino\}octadecanoate was calculated from the integration of the signals belonging to the methoxy group of the two diastereomers (see spectrum SI-17). This relative ratio was calculated from the spectrum of the crude reaction mixture. The product $(S, S)-8$ was then purified by preparative TLC on silica gel eluting with $\mathrm{CH}_{2} \mathrm{Cl}_{2}$ and scraping the spot with $\mathrm{RF} \sim 0.21$. The pure compound $(S, S)-8$ was extracted with $\mathrm{CHCl}_{3}$ and analyzed by NMR.

Methyl (9S)-9-\{[(2S)-2-(acetyloxy)-2-phenylacetyl]amino\}octadecanoate $[(S, S)-8]\left(\mathrm{C}_{29} \mathrm{H}_{47} \mathrm{NO}_{6}\right)$ : ${ }^{1} \mathrm{H}-\mathrm{NMR}\left(600 \mathrm{MHz}, \mathrm{CDCl}_{3}\right), \delta$ (ppm): 7.45-7.41 (m, $\left.2 \mathrm{H}\right), 7.39-7.32(\mathrm{~m} .3 \mathrm{H}), 6.03$ (s, $\left.1 \mathrm{H}\right), 5.66$ (br. d., $J$ $=9.44 \mathrm{~Hz}, 1 \mathrm{H}, \mathrm{NH}), 3.94-3.85(\mathrm{~m}, 1 \mathrm{H} . \mathrm{H}-9), 3.669\left(\mathrm{~s}, 3 \mathrm{H}, \mathrm{OCH}_{3}\right), 2.29(\mathrm{t}, J=7.61 \mathrm{~Hz}, 2 \mathrm{H}), 2.19(\mathrm{~s}, 3 \mathrm{H}$, $\left.\mathrm{CH}_{3} \mathrm{CO}\right), 1.64-1.14(\mathrm{~m}, 28 \mathrm{H}), 0.88\left(\mathrm{t}, J=7.04 \mathrm{~Hz}, 3 \mathrm{H}, \mathrm{CH}_{3}\right)$.

The same procedure was used to determine the optical purity of methyl (9R)-9- $\{[(2 S)-$ 2-(acetyloxy)-2-phenylacetyl]amino\}octadecanoate [(R,S)-8] $\left(\mathrm{C}_{29} \mathrm{H}_{47} \mathrm{NO}_{6}\right):{ }^{1} \mathrm{H}-\mathrm{NMR}\left(600 \mathrm{MHz}, \mathrm{CDCl}_{3}\right)$, $\delta$ (ppm): 7.45-7.42 (m, $2 \mathrm{H}), 7.39-7.33$ (m. 3H), 6.03 (s, $1 \mathrm{H}), 5.6$ (br. d., $J=9.04 \mathrm{~Hz}, 1 \mathrm{H}, \mathrm{NH}), 3.95-3.85$ $(\mathrm{m}, 1 \mathrm{H} . \mathrm{H}-9), 3.665\left(\mathrm{~s}, 3 \mathrm{H}, \mathrm{OCH}_{3}\right), 2.29(\mathrm{t}, J=7.61 \mathrm{~Hz}, 2 \mathrm{H}), 2.17\left(\mathrm{~s}, 3 \mathrm{H}, \mathrm{CH}_{3} \mathrm{CO}\right), 1.64-1.14(\mathrm{~m}, 28 \mathrm{H})$, $0.88\left(\mathrm{t}, J=7.04 \mathrm{~Hz}, 3 \mathrm{H}, \mathrm{CH}_{3}\right)$.

In order to verify if some signals of the two diastereisomers could be separated in the ${ }^{1} \mathrm{H}-\mathrm{NMR}$ spectrum, a mixture of $(\mathbf{S}, \mathbf{S})-\mathbf{8}$ and $(\boldsymbol{R}, \mathbf{S})-\mathbf{8}$ was prepared by mixing different amounts of the two species, 
previously purified by preparative TLC on silica gel $(20 \times 20 \mathrm{~cm}$ glass plates). The spectrum $(600 \mathrm{MHz})$ showed separate methoxyl hydrogen signals (see Figures S1-S18).

Finally, to confirm the assignment of the signals at 3.669 and $3.665 \mathrm{ppm}$ to the relative diastereomers, a small portion of purified $(\boldsymbol{R}, \mathbf{S})-\mathbf{8}$ was added to a solution of a 9:1 diastereomeric mixture of $\mathbf{8}$, and the peak at $3.665 \mathrm{ppm}$ increased, as expected.

\subsection{Cell Culture and Treatments}

The human colon cancer cell line HT29 was obtained from American Type Culture Collection (Manassas, VA, USA). The cells were cultured in RPMI 1640 medium (Labtek Eurobio, Milan, Italy), supplemented with 10\% FCS (Euroclone, Milan, Italy) and 2 mM L-glutamine (Sigma-Aldrich, Milan, Italy), at $37^{\circ} \mathrm{C}$ and $5 \% \mathrm{CO}_{2}$ atmosphere. These conditions were used in all cell incubation steps for the experiments described below. (R)-1, (S)-1, (R)-5 and (S)-5 were dissolved in ethanol to obtain a $33 \mathrm{mM}$ stock solution then diluted in culture medium to obtain the required concentrations. The cells were plated at a density of $1.0 \times 10^{4}$ cells/well in 6-well culture plates (Orange Scientific, Braine-l'Alleud, Belgium). Twenty-four hours after plating, $(R)-\mathbf{1}$ or $(S)-\mathbf{1}$ were added to a final concentration of $49 \mu \mathrm{M}$ or $51 \mu \mathrm{M}$ for each drug, and incubated for 24,48 , and $72 \mathrm{~h}$. Moreover, HT29 cells were seeded onto 6-well plates, and after $24 \mathrm{~h}$, they were treated with $(R)-5$ at the concentration of $57 \mu \mathrm{M}$ or with $(S)-5$ at the concentration of $43 \mu \mathrm{M}$ for 24,48 and $72 \mathrm{~h}$. The Trypan Blue exclusion dye method was used to determine the number of viable cells.

\subsubsection{MTT Assay}

To evaluate (R)-1, (S)-1, $(R)-\mathbf{5}$ and (S)-5 activity, the cells were treated for $24 \mathrm{~h}$ without (control) or with concentrations between $1 \mathrm{nM}-5 \mathrm{mM}(1 \mathrm{nM}, 5 \mathrm{nM}, 10 \mathrm{nM}, 50 \mathrm{nM}, 100 \mathrm{nM}, 500 \mathrm{nM}, 1 \mu \mathrm{M}$, $5 \mu \mathrm{M}, 10 \mu \mathrm{M}, 50 \mu \mathrm{M}, 100 \mu \mathrm{M}, 500 \mu \mathrm{M}, 1 \mathrm{mM}$ and $5 \mathrm{mM})$ of the test samples. The culture medium was removed and the cells were further incubated for $2 \mathrm{~h}$ with $0.2 \mathrm{mg} / \mathrm{mL}$ MTT in PBS. After removal of the medium, the cells were lysed with $0.1 \mathrm{~mL}$ of iso-propanol. The absorbance of the solubilized formazan pellet at $540 \mathrm{~nm}$ was determined by Victor2, Multilabel plate reader (Perkin Elmer, MI, Italy). The $\mathrm{IC}_{50}$ was determined from three different experiments of the dose-response curve by using GraphPadPrism 5 (GraphPad Software, Inc., La Jolla, CA, USA) fitting a symmetrical sigmoidal shaped curve.

\subsubsection{Cell Cycle Analysis by Flow Cytometry}

The HT29 cells were seeded in $25 \mathrm{~cm}^{2}$ flasks at a density of $2 \times 10^{4}$ cells $/ \mathrm{cm}^{2}$. The effects on the cell cycle were studied $48 \mathrm{~h}$ after treatment with $49 \mu \mathrm{M}(R)-\mathbf{1}$. To determine the cell cycle distribution at the end of incubation, HT29 cells were stained according to Busi et al. [23]. Briefly, $1 \times 10^{6}$ cells were pelleted and resuspended in trisodium citrate $0.1 \%$, RNAse $0.1 \mathrm{mg} / \mathrm{L}$, Igepal $0.01 \%$, Propidium Iodide (PI) $50 \mu \mathrm{g} / \mathrm{L}$. After $30 \mathrm{~min}$ at $37^{\circ} \mathrm{C}$ in the dark, the cells were analyzed on a Coulter Epics Elite flow cytometer (Beckman Coulter) equipped with an argon ion laser tuned at $488 \mathrm{~nm}$. PI fluorescence was collected on a linear scale at $600 \mathrm{~nm}$ and the DNA distribution was analyzed by the Modfit 5.0 software (ModFit Verity Software House http://www.vsh.com/).

\subsubsection{Histone Extraction and Western Blot}

HT29 cells were cultured with compounds $(\boldsymbol{R})-\mathbf{1}$ for $6 \mathrm{~h}$, and the histone fraction was extracted. The cells were harvested using $0.11 \%$ trypsin and $0.02 \%$ EDTA, washed twice with PBS, and nuclei were isolated according to Amellem et al. [24]. The nuclear histones were extracted, and proteins were quantified using a protein assay kit (Bio-Rad, Hercules, CA, USA). The histones were examined by $15 \%$ SDS-PAGE and a western blot analysis against acetylated lysines using anti-acetylated lysine (Cell Signaling Technology, Danvers, MA \#9441, USA). The detection of the immunoreactive bands was performed with a secondary antibody conjugated with horseradish peroxidase (Amersham, Uppsala, SE NA931V, Sweden) and developed with the enhanced chemiluminescence system Clarity Western 
(Bio-Rad, Hercules, CA, USA), and the quantification was done by Fluor-S Max Multilmager (Bio-Rad) using the histone H3 signal as the control (Cell Signaling Technology, Beverly, MA \#3638, USA).

\subsubsection{Total Protein Extraction and Western Blot}

HT29 cells were treated with $49 \mu \mathrm{M}$ of $(\boldsymbol{R})-\mathbf{1}$ for $24 \mathrm{~h}$. Cell were lysed in according to ref. 23. In brief, the cells were lysed for $20 \mathrm{~min}$ in an HEPES buffer and the protein concentration was determined by using the Bio-Rad protein assay method (Bio-Rad, Hercules, CA, USA). The proteins were resolved on a 10\% density gel and immunoblotted with p21 (Cell Signaling Technology, Danvers, MA\#2946, USA) or Myc (Cell Signaling Technology, Danvers, MA \#5605, USA) or $\beta$-actin (Cell Signaling Technology, Danvers, MA \#4967, USA) antibodies. The nitrocellulose membrane was incubated with secondary horseradish peroxidase-conjugated antibodies (GE Healthcare, Chicago, IL \#NA931V or \#NA9340, USA), developed as described in the previous section, and the quantification was done by Fluor-S Max Multilmager (Bio-Rad) using the $\beta$-actin signal as the control.

\subsubsection{Quantitative Real Time-PCR Analysis}

HT29 cells were seeded in $25 \mathrm{~cm}^{2}$ flasks at a density of $2 \times 10^{4}$ cells $/ \mathrm{cm}^{2}$ and treated with $(R)-1$ for $6 \mathrm{~h}$. RT-PCR was assessed as previously described [23]. The gene expression was quantified by $\triangle \triangle \mathrm{C}_{\mathrm{T}}$ method, by using GAPDH as the housekeeping gene. The following primers were used: $5^{\prime}-$ ATTTGGTCGTATTGGGCGCC-3' (forward) and 5'-ACGGTGCCATGGAATTTGCC-3' (reverse) for GAPDH detection, 5' -CCTAAGAGTGCTGGGCATTTT-3' (forward) and 5'-TGAATTTCATAACCGCCTGTG-3' (reverse) for P21 detection, 5'-TAGCTTCACCAACAGGAACT-3' (forward) and 5'-AGCTCGAATTTCTTCCAGAT-3' (reverse) for MYC detection.

\subsection{Statistical Analysis}

The data for the MTT, western blot, cell cycle and RT-PCR were analysed with a one-way analysis of variance (ANOVA) followed by Dunnett's multiple comparison test. The data of the cell growth were analysed with a two-way analysis of variance (ANOVA) followed by the Bonferroni multiple comparisons. The differences of at least $p<0.05$ were considered significant. A statistical analysis was carried out using Prism GraphPad software.

\section{Conclusions}

The novel derivatives of (9R)-9-hydroxystearic acid (9-HSA) have been synthesized and the influence of the modification at the level of the substituents on C-9 and of the carboxy group have been studied on HT 29 colon cancer cell line.

The modification on the C-9 by ester (namely methyl (9R)-9-\{[(4-methylphenyl)sulphonyl] oxy\}octadecanoate, $(\boldsymbol{R})-2$ ), by ether (namely methyl 9-methoxyoctadecanoate, 3 ), or azide group did not produce relevant antiproliferative activity on HT 29 cells. On the contrary, methyl (9S)-9-aminooctadecanoate [(S)-5] and its enantiomeric form $(R)-5$ was active against the above colon tumor cells, but very toxic, as evidenced by the high cytotoxicity after 48 and $72 \mathrm{~h}$ of the treatment. This is an indication of the importance, for a biological effect, to have a group bound to the C-9 with hydrogen atoms able to interact with the active site of the biological target. When the modification was at the carboxy group of 9-HSA, as in case of the formation of methyl esters $(\boldsymbol{R}) \mathbf{- 1}$ and $(S)-\mathbf{1}$, an antiproliferative effect was observed. In particular, $(R)-\mathbf{1}$ showed a more marked cytostatic effect compared to the (S)-1 enantiomer. In fact, the number of cells dropped at $24 \mathrm{~h}$ and remained unchanged over time, suggesting a halt in cell growth. The anti-proliferative effect induced by $(R)-\mathbf{1}$ is characterized by an accumulation of cells in the G0 / G1 phase. The antiproliferative effect of the $(R)-\mathbf{1}$ is due to an increase of the p21WAF/CYP1 and a decrease of c-myc expression that is reflected on these two protein levels.

Supplementary Materials: The following are available online: Figures S1-S18: ${ }^{1} \mathrm{H}$ and ${ }^{13} \mathrm{C}-\mathrm{NMR}$ spectra of compounds 1-8. 
Author Contributions: Conceptualization, C.B. and N.C.; investigation, C.B., N.C., D.T., C.T., G.M.; resources, C.B., N.C., G.S., S.B.; writing-original draft preparation, C.B., N.C.; writing-review and editing, S.B., G.S. All authors have read the final version of the manuscript.

Funding: This research received no external funding.

Acknowledgments: Work supported by Alma Mater Studiorum-Università di Bologna (RFO funds). Authors thank Luca Prati, Isabel Orlando, Arige Othman, and Luca Zuppiroli for running the mass spectra.

Conflicts of Interest: The authors declare no conflicts of interest.

\section{References}

1. Masotti, L.; Casali, E.; Gesmundo, N.; Sartor, G.; Galeotti, T.; Borrello, S.; Piretti, M.V.; Pagliuca, G. Lipid peroxidation in cancer cells: Chemical and physical studies. Ann. N. Y. Acad. Sci. 1989, 551, 47-58. [CrossRef] [PubMed]

2. Masotti, L.; Casali, E.; Gesmundo, N. Influence of hydroxystearic acid on in vitro cell proliferation. Mol. Aspects Med. 1993, 14, 209-215. [CrossRef]

3. Bertucci, C.; Hudaib, M.; Boga, C.; Calonghi, N.; Cappadone, C.; Masotti, L. Gas chromatography/mass apectrometry assay of endogenous cellular lipid peroxidation products: Quantitative analysis of 9- and 10-hydroxystearic acids. Rapid Commun. Mass Spectrom. 2002, 16, 859-864. [CrossRef] [PubMed]

4. Calonghi, N.; Cappadone, C.; Pagnotta, E.; Farruggia, G.; Buontempo, F.; Boga, C.; Brusa, G.L.; Santucci, M.A.; Masotti, L. 9-Hydroxystearic acid upregulates p21WAF1 in HT29 cancer cells. Biochem. Biophys. Res. Commun. 2004, 314, 138-142. [CrossRef]

5. Calonghi, N.; Pagnotta, E.; Parolin, C.; Molinari, C.; Boga, C.; Dal Piaz, F.; Brusa, G.L.; Santucci, M.A.; Masotti, L. Modulation of apoptotic signalling by 9-hydroxystearic acid in osteosarcoma cells. Biochim. Biophys. Acta, Mol. Cell. Biol. Lipids 2007, 1771, 139-146. [CrossRef]

6. Boanini, E.; Torricelli, P.; Boga, C.; Micheletti, G.; Cassani, M.C.; Fini, M.; Bigi, A. (9R)-9-HydroxystearateFunctionalized Hydroxyapatite as Anti-Proliferative and Cytotoxic Agent towards Osteosarcoma Cells. Langmuir 2016, 32, 188-194. [CrossRef]

7. Calonghi, N.; Cappadone, C.; Pagnotta, E.; Boga, C.; Bertucci, C.; Fiori, J.; Tasco, G.; Casadio, R.; Masotti, L. Histone deacetylase 1: A target of 9-hydroxystearic acid in the inhibition of cell growth in human colon cancer. J. Lipid Res. 2005, 46, 1596-1603. [CrossRef]

8. Calonghi, N.; Pagnotta, E.; Parolin, C.; Tognoli, C.; Boga, C.; Masotti, L. 9-Hydroxystearic acid interferes with EGF signalling in a human colon adenocarcinoma. Biochem. Biophys. Res. Commun. 2006, 342, 585-588. [CrossRef]

9. West, A.C.; Johnstone, R.W. New and emerging HDAC inhibitors for cancer treatment. J. Clin. Invest. 2014, 124, 30-39. [CrossRef]

10. Earle, F.R.; Mikolajczak, K.L.; Wolff, I.A.; Barclay, A.S. Search for new industrial oils. X. Seed oils of the calenduleae. J. Am. Oil Chem. Soc. 1964, 41, 345-347. [CrossRef]

11. Parolin, C.; Calonghi, N.; Presta, E.; Boga, C.; Caruana, P.; Naldi, M.; Andrisano, V.; Masotti, L.; Sartor, G. Mechanism and stereoselectivity of HDAC I inhibition by (R)-9-hydroxystearic acid in colon cancer. Biochim. Biophys. Acta 2012, 1821, 1334-1340.

12. Ebert, C.; Felluga, F.; Forzato, C.; Foscato, M.; Gardossi, L.; Nitti, P.; Pitacco, G.; Boga, C.; Caruana, P.; Micheletti, G. Enzymatic kinetic resolution of hydroxystearic acids: A combined experimental and molecular modelling investigation. J. Molec. Catal. B: Enzymatic 2012, 83, 38-45. [CrossRef]

13. Bayley, H.; Standring, D.N.; Knowles, J.R. Propane-1,3-di-thiol: A selective reagent for the efficient reduction of alkyl and aryl azides to amines. Tetrahedron Lett. 1978, 39, 3633-3634. [CrossRef]

14. Boga, C.; Drioli, S.; Forzato, C.; Micheletti, G.; Nitti, P.; Prati, F. Easy route to enantiomerically enriched 7and 8-hydroxy-stearic acids by olefin-metathesis-based approach. Synlett 2016, 27, 1354-1358.

15. Richon, V.M.; Sandhoff, T.W.; Rifkind, R.A.; Marks, P.A. Histone deacetylase inhibitor selectively induces p21WAF1 expression and gene-associated histone acetylation. Proc. Natl. Acad. Sci. USA 2000, 97, 10014-10019. [CrossRef] [PubMed]

16. Nakano, K.; Mizuno, T.; Sowa, Y.; Orita, T.; Yoshino, T.; Okuyama, Y.; Fujita, T.; Ohtani-Fujita, N.; Matsukawa, Y.; Tokino, T.; et al. Butyrate activates the WAF1/Cip1 gene promoter through Sp1 sites in a p53-negative human colon cancer cell line. J. Biol. Chem. 1997, 272, 22199-22206. [CrossRef] [PubMed] 
17. Huang, L.; Sowa, Y.; Sakai, T.; Pardee, A.B. Activation of the p21WAF1/CIP1 promoter independent of p53 by the histone deacetylase inhibitor suberoylanilide hydroxamic acid (SAHA) through the Sp1 sites. Oncogene 2000, 19, 5712-5719. [CrossRef]

18. Dang, C.V. MYC, metabolism, cell growth, and tumorigenesis. Cold Spring Harb. Perspect. Med. 2013, 3, a014217. [CrossRef]

19. Lawlor, E.R.; Soucek, L.; Brown-Swigart, L.; Shchors, K.; Bialucha, C.U.; Evan, G.I. Reversible kinetic analysis of Myc targets in vivo provides novel insights into Myc-mediated tumorigenesis. Cancer Res. 2006, 66, 4591-4601. [CrossRef]

20. Sodir, N.M.; Swigart, L.B.; Karnezis, A.N.; Hanahan, D.; Evan, G.I.; Soucek, L. Endogenous Myc maintains the tumor microenvironment. Genes Dev. 2011, 25, 907-916. [CrossRef]

21. Wolfer, A.; Wittner, B.S.; Irimia, D.; Flavin, R.J.; Lupien, M.; Gunawardane, R.N.; Meyer, C.A.; Lightcap, E.S.; Tamayo, P.; Mesirov, J.P.; et al. MYC regulation of a "poor-prognosis" metastatic cancer cell state. Proc. Natl. Acad. Sci. USA 2010, 107, 3698-3703. [CrossRef] [PubMed]

22. Cochrane, C.; Harwood, H.J. Phase properties of mixtures of 9- and 10-oxo-octadecanoic acids and of 9- and 10-hydroxyoctadecanoic acids. J. Org. Chem. 1961, 26, 1278-1282. [CrossRef]

23. Busi, A.; Aluigi, A.; Guerrini, A.; Boga, C.; Sartor, G.; Calonghi, N.; Sotgiu, G.; Posati, T.; Corticelli, F.; Fiori, J.; et al. Unprecedented behavior of (9R)-9-hydroxystearic acid loaded keratin nanoparticles on cancer cell cycle. Mol. Pharmaceutics 2019, 16, 931-942. [CrossRef] [PubMed]

24. Amellem, O.; Stokke, T.; Sandvik, J.A.; Pettersen, E.O. The retinoblastoma gene product is reversibly dephosphorylated and bound in the nucleus in S and G2 phases during hypoxic stress. Exp. Cell Res. 1996, 227, 106-115. [CrossRef]

Sample Availability: Samples of the compounds are not available from the authors.

(C) 2019 by the authors. Licensee MDPI, Basel, Switzerland. This article is an open access article distributed under the terms and conditions of the Creative Commons Attribution (CC BY) license (http://creativecommons.org/licenses/by/4.0/). 